\title{
The environmental relevance of freshwater consumption in global power production
}

\author{
Journal Article \\ Author(s): \\ Pfister, Stephan; Saner, Dominik; Koehler, Annette \\ Publication date: \\ 2011-07 \\ Permanent link: \\ https://doi.org/10.3929/ethz-b-000037866 \\ Rights / license: \\ In Copyright - Non-Commercial Use Permitted
}

Originally published in:

The International Journal of Life Cycle Assessment 16(6), https://doi.org/10.1007/s11367-011-0284-8 


\title{
The environmental relevance of freshwater consumption in global power production
}

\author{
Stephan Pfister • Dominik Saner • Annette Koehler
}

Received: 11 October 2010 /Accepted: 28 March 2011 / Published online: 3 May 2011

(C) Springer-Verlag 2011

\begin{abstract}
Purpose Freshwater use and consumption is of high environmental concern. While research has primarily focused on agricultural water use, industrial water use has recently become more prominent. Because most industries employ relatively low amounts of water, our study focuses on electricity production, which is involved in almost all economic activities and has a considerable share of the global water consumption.

Materials and methods Water consumption data for different power production technologies was calculated from literature. Due to the global importance of hydropower and the high variability of its specific water consumption, a climate-dependent estimation scheme for water consumption in hydroelectric generation was derived. Applying national power production mixes, we analyzed water consumption and related environmental damage of the average power production for all countries. For the European and North American countries, we further modeled electricity trade to assess the electricity market mix and the power-consumption related environmental damages. Using the Eco-indicator 99 single-score and compatible freshwater consumption damage assessments,
\end{abstract}

Electronic supplementary material The online version of this article (doi:10.1007/s11367-011-0284-8) contains supplementary material, which is available to authorized users.

S. Pfister $(\bowtie) \cdot$ D. Saner $\cdot$ A. Koehler

ETH Zurich, Institute of Environmental Engineering,

8093 Zurich, Switzerland

e-mail: pfister@ifu.baug.ethz.ch

A. Koehler

PE International Switzerland,

Löwenstrasse 20,

8001 Zurich, Switzerland the contribution of water consumption to the total environmental impact was quantified.

Results and discussion Water consumption dominates the environmental damage of hydropower, but is generally negligible for fossil thermal, nuclear, and alternative power production. However, as the impact of water consumption has high regional variation, it can be relevant for many power technologies in water-scarce areas. The variability among country production mixes is substantial, both from a water consumption and overall environmental impact perspective. The difference between electricity production and market mixes is negligible for most countries, especially for big countries such as the USA. In Europe, where intensive international electricity trade exists, the difference is more significant. When contrasted with the relatively high uncertainties in water consumption figures particularly for hydropower, the additional error from using production mixes instead of market mixes is rather small.

Conclusions Power production is one of the major global water consumers and involved in life cycles of almost any human activity. Covering the water-consumption-related environmental damage of power generation closes one important gap in life cycle assessment and also improves data availability for the emerging field of water footprints.

Keywords Dams · Life cycle assessment $\cdot$ Life cycle impact assessment Power production - Regionalization - Water consumption

\section{Introduction}

Water resources have only recently been addressed in life cycle assessment (LCA) and their assessment still lacks wide application. With annual withdrawals of 4000 billion 
tonnes of freshwater (Rockstrom et al. 2009) including 700 billion tonnes of groundwater (Zektser and Everett 2007), it is by far the most extracted natural resource by mass, and its related environmental impacts need to be quantified and evaluated. Currently, reliable water inventories for most economic sectors are quite sparse, and meaningful assessments are limited. Some LCA databases, such as the ecoinvent v2.1 database (Ecoinvent Centre 2008), provide basic data on water use, and most available life cycle impact assessment methods differentiate consumptive and degradative water use (Pfister et al. 2009a; Mila i Canals et al. 2009; Bayart et al. 2010). Water consumption (consumptive use) denotes the part of the freshwater which is not released back to the original watershed; primarily due to evaporation and product integration. Other operational impact assessment methods provide characterization factors for water withdrawals based on a water stress index (Frischknecht et al. 2008) and exergy (Bosch et al. 2007).

Agriculture is responsible for $85 \%$ of the overall global freshwater consumption (Shiklomanov 2003), and causes significant environmental damages (Pfister et al. 2009a; Pfister et al. 2009b). Power production represents the vast majority of industrial water consumption. In the USA, power generation uses more freshwater than irrigation in agriculture (Weber et al. 2010). Yet, the consumptive share of water used in US power production is still much lower than in agriculture. Reservoirs and cooling water use, both relevant for power production, have been identified as globally important water consumers (Mila i Canals et al. 2009). However, a comprehensive analysis of water-userelated environmental impacts caused by power generation is still lacking: regionally specific water use impacts and the influence of the local climate on evaporation rates from reservoirs and on cooling water requirements have not been addressed.
In this paper, we provide global data on direct freshwater consumption in power production with a country-level resolution and analyze the relevance of water-use-related environmental impacts in comparison to traditional LCA impact categories. We further calculate water consumption and related impacts of electricity market mixes in 29 European countries, Canada, Mexico, and the United States, analyzing the effect of international electricity trade.

\section{Methods}

2.1 Specific water consumption for different power production systems

We analyze water consumption (i.e., the part of water that is not released back to the watershed of origin) of different power production systems by screening publicly available datasets. Data on water consumption is limited, as most reported data account for total water use, i.e. withdrawals. From an environmental point of view, however, total water use is less relevant than water consumption because consumed freshwater reduces freshwater availability for downstream users such as ecosystems. Withdrawn water which is released back to the environment with a reduced quality (degradative water use) and associated potential adverse effects on the environment are mainly captured by the impact assessment of the related emissions. Most of the reports differentiate among hydropower, fossil thermal (oil, coal, and natural gas), nuclear and alternative (including wind, solar, waste and geothermal) power production. Some publications additionally specify consumptive water use for different technologies and different climates (Table 1). In this study, we analyze electricity generated by technology groups: hydropower, fossil thermal, nuclear,

Table 1 References used to estimate specific water consumption in power generation

\begin{tabular}{ll}
\hline Reference & Power production types described \\
\hline $\begin{array}{l}\text { National Renewable Energy Laboratory (NREL), US (Torcellini et al. 2003) } \\
\text { American Wind Energy Association (AWEA), US (Feeley et al. 2006) }\end{array}$ & $\begin{array}{l}\text { Hydropower and total thermal (per US state) } \\
\text { Coal, nuclear, natural gas, oil, wind, PV }\end{array}$ \\
Southern Illinois University Carbondale, US (Dziegielewski and Bik 2006) & Fossil thermal and nuclear (including ranges) \\
The University of Texas at Austin, US (Stillwell et al. 2009) & Fossil thermal, coal, three types of natural gas, nuclear, \\
& concentrated solar power (including ranges) \\
US Department of Energy, US (Melillo et al. 2009) & Total thermal, geothermal (US average) \\
U.S. Geological Survey, US (Solley et al. 1998) & Total thermal (US average) \\
Gleick PH, US, (1994) & $\begin{array}{l}\text { Hydropower } \\
\text { Electric Power Research Institute (EPRI), US, (EPRI 2002) }\end{array}$ \\
EPRI and US Department of Energy, US (EPRI and U.S. Department of Energy 1997) & Geothermal \\
Aquapower, Switzerland (SN Energie Gruppe 2008) & Hydropower (Swiss case) \\
Kadigi et al. (2008), Tanzania & Hydropower (Tanzanian case) \\
\hline
\end{tabular}

The sources specifically list water consumption of different power production types 
and alternative power generation. The latter encompasses wind, solar, waste and geothermal installations, as well as small-scale hydropower and electricity production from waste materials and waste heat. We assume that the only water input for power plants is freshwater. This is a simplification as the source of water depends on the geographic location and cannot be addressed in detail in this analysis. As plants located along the coastline often apply saltwater for cooling purposes, this assumption represents an overestimation of freshwater consumption for power plants using seawater. Based on the considerable variability of reported power plants' water consumption figures, we estimate low and high boundaries of direct water consumption to reflect different available technologies within a technology group (Table 2). These values are considered as the $95 \%$ confidence interval and are applied to derive dispersion factors ( $k$ values) as described by Slob (1994).

For fossil thermal and nuclear power generation, infrastructure and fuel provision are generally of low overall environmental importance (Peiu 2007) and water consumption is also relatively low (Fthenakis and Kim 2010). In contrast, for hydropower and most alternative energy generation plants (e.g., photovoltaics), infrastructure significantly contributes to the total environmental performance (Ribeiro and da Silva 2010). Water consumption for infrastructure of all technologies, however, only marginally adds to the environmental profile. For hydropower, water consumption related to mixing concrete accounts for less than $1 \%$ of the overall life cycle water consumption. Accordingly, we analyze water consumption only during the operations phase of power generation, while the full life cycle is included for all other impact categories.

\subsection{Regional water consumption of hydropower production} including climatic factors

Hydropower is the most significant consumer of water with high differences among power stations, mainly due to specific plant geometry and climate. Region-specific water consumption of hydropower installations is calculated with state-level data from the USA (Torcellini et al. 2003) and climatic data. In this study, plant geometry and other specific infrastructure characteristics are not included, as this information is not available for the datasets used. We use potential evapotranspiration (PET) and aridity data of the region where the hydroelectric installations are located as proxy for climatic conditions. PET directly influences consumptive water use in water storages, and aridity relates evaporation to water availability. The latter determines the water flows, and consequently the required storage time, per unit of electricity generated. Aridity is expressed by an aridity index $(\mathrm{AI})$, which denotes the quotient of precipitation $(P)$ and PET. PET (FAO 2004) and $P$ data (New et al. 2002), which are both available on a 10 -arcmin resolution, are aggregated on state level considering the reported locations of hydropower plants in the USA (National Atlas 2009). We include only those stations for which hydropower generation is the first or second operating priority (besides, e.g., irrigation). To derive a climate-dependent water consumption function, we perform separate linear regressions of PET and $\log (\mathrm{AI})$ with hydropower water consumption data on the state level. The specific hydropower water consumption at location $i\left(\mathrm{WC}_{\mathrm{hydro}, i}\right)$ is the average result of the two linear regression functions for PET $\left(\mathrm{WC}_{\mathrm{PET}, i}\right)$ and $\log (\mathrm{AI})\left(\mathrm{WC}_{\mathrm{AI}, i}\right)$ :

$$
\begin{aligned}
\mathrm{WC}_{\text {hydro }, i} & =\frac{\mathrm{WC}_{\mathrm{PET}, i}+\mathrm{WC}_{A I, i}}{2} \\
& =\frac{\mathrm{PET}_{i}}{1152} \times 12.50+10^{\left(-0.6531 A I_{i}+2.338\right)} \times 0.1544
\end{aligned}
$$

The relation of the model results $\left(\mathrm{WC}_{\text {hydro }}\right)$ with the measured values is represented by a Pearson correlation coefficient of 0.77 at a high significance level (Electronic Supplementary Material (ESM), Table S1). Still, this function only covers a limited range of the variability of USA state-specific water consumption in hydropower production: The lowest and highest $\mathrm{WC}_{\mathrm{hydro}, i}$ results of individual USA states are applied to calculate the $95 \%$

Table 2 Calculated average direct water consumption of main power production technologies including high and low estimates $\left[\mathrm{m}^{3} / \mathrm{MWh}\right]$ based

\begin{tabular}{|c|c|c|c|c|}
\hline \multirow[t]{2}{*}{ Power generation technology } & \multicolumn{4}{|c|}{ Water consumption $\left[\mathrm{m}^{3} / \mathrm{MWh}\right]$} \\
\hline & Average & Low estimate & High estimate & $k_{95 \%}$ \\
\hline Fossil thermal & 1.5 & 0.6 & 2.0 & 1.8 \\
\hline Nuclear & 2.3 & 1.5 & 3.5 & 1.5 \\
\hline Hydropower & 25 & 1.0 & 600 & 24.5 \\
\hline Alternative (wind, solar, waste, geothermal, and others) & 0.2 & 0.004 & 4.4 & 33.2 \\
\hline
\end{tabular}
on the sources outlined in Table 1

$k_{95 \%}$ is the dispersion factor used to describe the uncertainty in a log-normal distribution representing the $95 \%$ confidence interval (Slob 1994 ) 
interval resulting in a $k$ factor of 2.81. Modeling climatespecific water consumption thereby reduces the remaining uncertainty according to error propagation from a $k$ factor of 24.5 to 20.6 , which represents the geometry-related variability. Specific water consumption of hydropower is calculated for each country based on country average $P$ and AI data. In the United States, we use the state-level differentiated results and derive corresponding statespecific damage factors. All water consumption is allocated to electricity generation, even for dams with multiple purposes (e.g., irrigation and drinking-water supply), as there is no way to allocate such damages objectively even on USA state level, and basic power production has usually the highest priority (Torcellini et al. 2003). This allocation procedure is reasonable for estimating the upper boundaries of the environmental impact of water consumption in hydropower generation.

\subsection{Water consumption and related impacts in national power production mixes}

On a global scale, data availability is restricted to reports on national power production, i.e., with a country-level resolution, and no consistent water consumption information is available. To set up a global inventory of water consumption in power production, we use national electricity production data of the year 2005 (Energy Information Administration 2009) and apply the water consumption estimates derived above (Section 2.1 and Section 2.2 for hydropower) to the respective generation technologies of the national production mixes. We assess these production mixes with country-specific characterization factors for water consumption following the method of Pfister et al. (2009a).

\subsection{Relevance of water consumption impacts in power production}

\subsubsection{Environmental damage of global and national power production}

For each power production technology, we derive an average global inventory using the average of all technology-specific datasets for different countries available in the ecoinvent database (Ecoinvent Centre 2008). We calculate the global electricity mix and related environmental damage, employing the country electricity production mixes, the global average technology-specific inventories, and the Ecoindicator 99 (EI99HA) methodology (Goedkoop and Spriensma 2001) for impact assessment. The environmental damages of the associated water consumption, as calculated in Section 2.3, represent regionalized results compliant with EI99HA (Pfister et al. 2009a). We use these data to quantify the relevance of water-use-related impacts in power production systems for individual countries and the global electricity mix. The single-score assessment according to EI99HA, including water consumption damages, is denoted "EI99+". The calculated damage is valid for marginal changes in power consumption as water-related damage is non-linear (Pfister et al. 2009a). For the global power mix, we therefore assess the marginal change of electricity production, and assume the current technology mix.

\subsubsection{Uncertainties}

For each electricity generation technology, the uncertainties of environmental impacts are derived on two levels: regional variability, and the uncertainty of life cycle environmental flows (emissions and resource consumption) of individual power production technologies. For this purpose, the available datasets in the ecoinvent database v2.1 (Ecoinvent Centre 2008) are analyzed. The $k$ factors for regional variability of inventory flows are aggregated per impact-category based on the impact assessment results (EI99HA scores) of different datasets representing the same technology, assuming log-normal distributions (Slob 1994). The propagation of uncertainty of individual environmental flows into the EI99 impact-category damage scores is analyzed by Monte-Carlo analysis for the following ecoinvent processes, which we assume to represent generic uncertainty of inventories for the respective power generation technologies: (1) "Electricity, hard coal, at power plant/UCTE U" for coal power, (2) "Electricity, natural gas, at power plant/UCTE U, Electricity" for gas power, (3) "Electricity, nuclear, at power plant/UCTE U" for nuclear power and (4) "Electricity, hydropower, at power plant/DE U" for hydropower. The resulting 2.5 and 97.5 percentiles are used to calculate $k$ factors. The combined uncertainty of generic environmental flow uncertainty and regional variability is computed through error propagation (Slob 1994), assuming these factors to be uncorrelated. As alternative power production is very heterogeneous and of minor importance on global scale, we did not analyze these technologies in further detail.

\subsection{Water consumption in national power market mixes}

Due to international trade of electricity, power production and market mixes within countries might differ considerably. To assess the consequences on environmental damages, we analyze the electricity trade for the North American and European markets. We follow the approach suggested by Frischknecht et al. (2007): electricity imports and national production are inputs to a national power market mix, which again is exported to other countries and hence includes proportional re-export of imported power. In 
order to properly describe the electricity trade system of $n$ countries, we create a technosphere matrix $\mathbf{T}$ separating power production $(\mathrm{P})$ and power markets $(\mathrm{M})$. $\mathbf{T}$ consists of four sub-matrices with $n^{\mathrm{x}} n$ elements, where $n$ is the number of countries: production to production (PP), production to market (PM), market to production (MP) and market to market (MM):

$\mathbf{T}=\left(\begin{array}{ll}\mathbf{P P} & \mathbf{P M} \\ \mathbf{M P} & \mathbf{M M}\end{array}\right)$

The PP and MP matrices are set to zero for two reasons: (a) according to the modeling approach in the ecoinvent v2.1 database, we assume power production and its supply chain to use electricity supplied by the market and not from production itself (PP). (b) This electricity supply from the market to the power plant is modeled on plant-process level and thus not further considered on the level of the national production mix (MP). Power use involved in power generation (e.g., electricity used to pump water to pumped-storage hydropower plants) is therefore a background process of our trade system and omitted in the market mix calculations. $\mathbf{P M}$ is a diagonal matrix depicting the shares of own nation-wide production in the national power market mixes, and MM describes the shares of border-crossing electricity imports of each country from its neighboring countries. The electricity market mix of a country's final supply is derived from solving the following equation according to Leontief (1970):

$\mathbf{X}=(\mathbf{I}-\mathbf{T})^{-1}=\left(\begin{array}{cc}\mathbf{P P}_{\mathbf{x}} & \mathbf{P M}_{\mathbf{x}} \\ \mathbf{M P}_{\mathbf{x}} & \mathbf{M M}_{\mathbf{x}}\end{array}\right)$

where $\mathbf{X}$ is the resulting process activity matrix and $\mathbf{I}$ the identity matrix. $\mathbf{X}$ has a format equivalent to $\mathbf{T}$ and describes the process activity (matrix rows) required to produce the output of each process (matrix columns). The $n^{\mathrm{x}} n$ elements of the upper right quadrant of $\mathbf{X}\left(\mathbf{P M}_{\mathbf{x}}\right)$ show the electricity shares of all producing countries contributing to the electricity market mix of a selected country (columns sum up to 1) and represents the main result to be multiplied with the electricity demand vector. The $n^{\mathrm{x}} n$ elements in the lower right quadrant $\left(\mathbf{M M}_{\mathbf{x}}\right)$ indicate the cross-market electricity flows induced by electricity trading (diagonal elements are $>1$ if re-exports exist). $\mathbf{P P}_{\mathbf{x}}$ is an identity matrix (i.e., production mix of $1 \mathrm{kWh}$ requires a production mix with $1 \mathrm{kWh}$ output) and $\mathbf{M} \mathbf{P}_{\mathbf{x}}$ equals zero (i.e., there is no market mix input for the production mix).

For the calculation of European electricity market mixes, we use the cross-border power exchange and national power production data provided by European Network of Transmission System Operators for Electricity (ENTSO-E, 2010). The most recent data is valid for the year 2007 and covers 29 European countries (all ENTSO-E member states excluding Latvia, Lithuania, and Estonia). For the North American electricity market mixes, we apply trade data reported by the US Energy Information Administration (EIA) for the year 2007 (Energy Information Administration 2009). The national power market mixes are calculated using the specific inventories and impact scores of power generation technologies (see Section 2.3 and 2.4) of the exporting countries.

\subsection{Spatially explicit distribution of water consumption in thermal power production}

Thermal power generation generally includes nuclear and fossil thermal (coal, gas, oil) power production plants. Water consumption estimates for thermal power generation are provided on a global level by Alcamo and colleagues (GWSP Digital Water Atlas 2008). They modeled total water consumption of thermal power production on a high spatial resolution ( 0.5 arcmin), but have not provided specific consumption factors per electricity amount produced. To check the representativeness of the water consumption values for thermal power generation presented in Table 2, we aggregate their water consumption data on country level and perform a multiple linear regression with the country-specific nuclear and fossil thermal electricity generation as reported by EIA. This analysis results in specific water consumption estimates for fossil thermal and nuclear power (Table 3 ) which are only $48 \%$ and $72 \%$ of the values calculated above (see Table 2). In addition to this comparison, Alcamo's data set is used to plot the total environmental damage of water consumption in thermal power production in each model cell (roughly $50 \mathrm{~km} \times$ $50 \mathrm{~km}$ ) applying the geographically specific impact characterization factors from Pfister et al. (2009a).

\section{Results}

\subsection{Regional environmental impact of water consumption}

The freshwater-consumption-related environmental damages of the electricity production mixes of 208 countries were calculated and the results are provided as a separate XLS file in the ESM, together with the corresponding environmental damages computed in the standard EI99HA assessment and the global warming potential with a 100-year time horizon (GWP 100a), according to IPCC (2007). The file also includes respective dispersion factors and impact scores per area of protection. A map of the water consumption volumes and related damages per megawatt-hour of electricity produced in each country is presented in Fig. 1a-b.

In addition, environmental impacts of water consumption in the global power production mix were calculated as estimates to be applied for electricity consumption in background processes (see Section 2.3 and Table 4). The 
Table 3 Country-specific water consumption in thermal power production based on Alcamo et al. (GWSP Digital Water Atlas 2008) using multiple linear regression total water consumption per country and respective power production data from EIA (Energy Information Administration 2009)

\begin{tabular}{lcrr}
\hline Power generation technology & \multicolumn{2}{l}{} \\
\cline { 2 - 4 } & Water consumption $\left[\mathrm{m}^{3} / \mathrm{MWh}\right]$ & \\
\cline { 2 - 4 } & Global average & $2.5 \%$ percentile & $97.5 \%$ percentile \\
\hline Fossil thermal & 0.7 & 0.1 & 1.9 \\
Nuclear & 1.7 & 0.3 & 4.3 \\
Total thermal & 1.1 & 0.2 & 4.0 \\
\hline
\end{tabular}

The global average and percentiles are weighted by the countries' generation of thermal power

damage scores of the global power mix are mainly caused by the $17 \%$ share of hydropower.

Water consumption is particularly important in many water-abundant countries, e.g., Brazil, Norway, Congo, Switzerland, and Canada, because of high shares of hydropower. In contrast, high environmental damage from water consumption is mainly observed in water-scarce countries which operate some hydropower plants, for instance in Pakistan, Afghanistan, Egypt, and Peru. Countries such as the USA, Australia, and Egypt feature high per-capita reduction potentials as indicated by the per-capita environmental impact of national power generation (see Fig. 1c). The regionally specific water consumption of thermal power production demonstrates the spatial distribution and concentration of environmental damages, pinpointing parts of Europe, the Americas, and Asia that suffer from relevant water pressures induced by thermal power generation (see Fig. 1d). Environmental hotspots are especially found in arid regions such as Egypt, whereas in Europe and the eastern
USA environmental impacts are spatially distributed and not concentrated on a small area (see Fig. 1d).

\subsection{Contribution of water consumption to overall environmental damage-regional differences and uncertainties}

The overall environmental assessment of the global average electricity production mix (see Sections 2.3 and 2.4) indicates that water consumption is of rather minor relevance for the thermal production technologies, while for hydropower it contributes to the vast share of the total environmental damage (79\% of EI99+ single-scores, Fig. 2). Compared to fossil thermal production systems, hydropower causes only low overall environmental damage per electricity unit produced. Interestingly, hydropower performs worse overall than nuclear power generation according to the EI99+ assessment.

Table 5 provides a selection of countries with high importance of water consumption due to high shares of
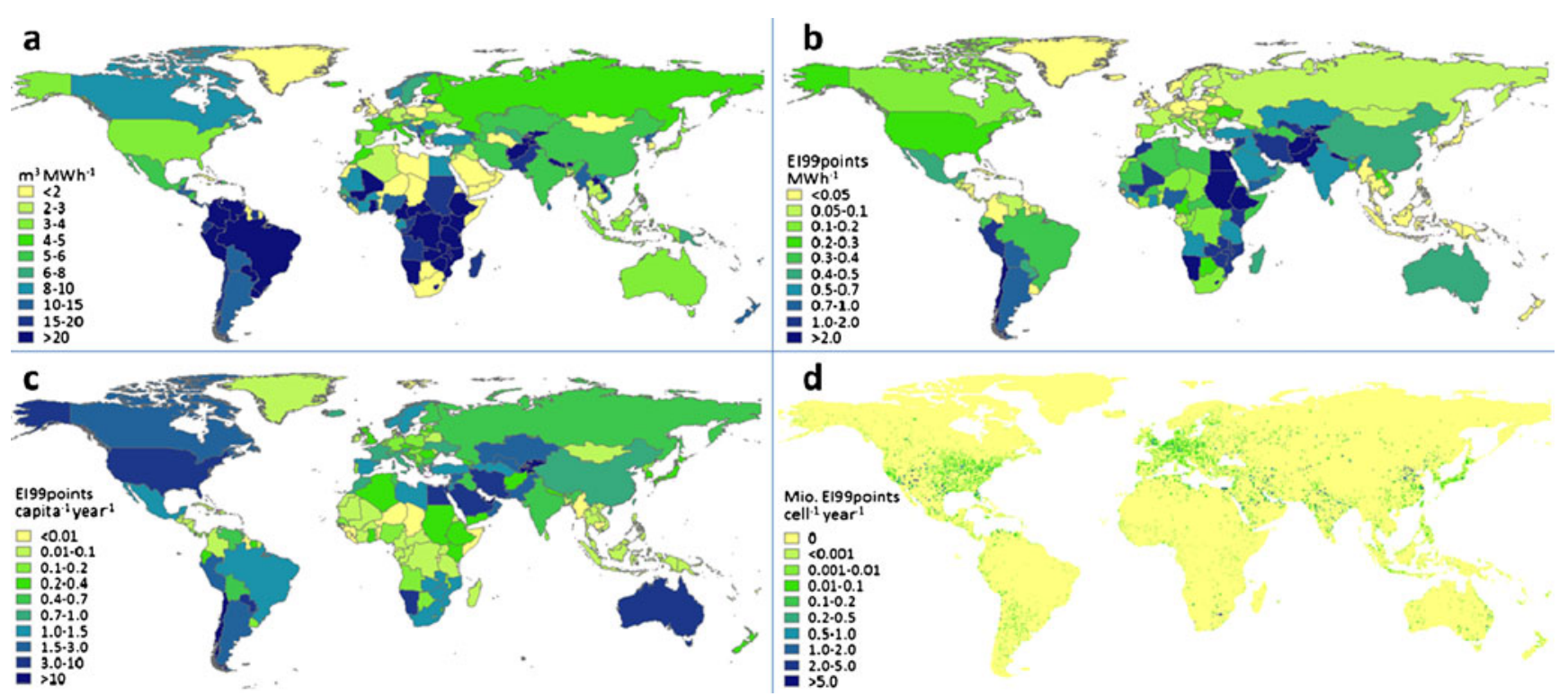

Fig. 1 Water consumption and related impacts of the national power production mixes: a Country-specific inventory, b Country-specific aggregated EI99+ damage scores per MWh of electricity produced, $\mathbf{c}$

Country-specific environmental damage per-capita and year. d Spatial distribution of environmental impact summed per model cell $\left(0.5^{\circ}\right.$ resolution) and year for thermal power production only 
Table 4 Global average environmental impact of water consumption in power production, including high and low estimates for each power production technology. Values are calculated on the basis of countryspecific production mixes and related water-consumption damages.
Low and high estimates are based on low and high water consumption estimates of the selected technologies (Table 2), except for hydropower for which climate dependent values were applied (section 2.3)

\begin{tabular}{|c|c|c|c|c|}
\hline & & \multicolumn{3}{|c|}{ Water consumption } \\
\hline & & $\begin{array}{l}\text { Average } \\
{[\mathrm{m} 3 / \mathrm{MWh}]}\end{array}$ & $\begin{array}{l}\text { Low estimate } \\
{[\mathrm{m} 3 / \mathrm{MWh}]}\end{array}$ & $\begin{array}{l}\text { High estimate } \\
{[\mathrm{m} 3 / \mathrm{MWh}]}\end{array}$ \\
\hline \multicolumn{2}{|l|}{ Global power mix } & 5.55 & 0.79 & 103 \\
\hline & & \multicolumn{3}{|c|}{ Water consumption related environmental damages } \\
\hline $\begin{array}{l}\text { Power generation } \\
\text { technology }\end{array}$ & Global production share & $\begin{array}{l}\text { Average } \\
\text { [EI99-pts/MWh] }\end{array}$ & $\begin{array}{l}\text { Low estimate } \\
\text { [EI99-pts/MWh] }\end{array}$ & $\begin{array}{l}\text { High estimate } \\
\text { [EI99-pts/MWh] }\end{array}$ \\
\hline Fossil thermal & $66 \%$ & 0.12 & 0.05 & 0.16 \\
\hline Nuclear & $15 \%$ & 0.09 & 0.06 & 0.13 \\
\hline Hydropower & $17 \%$ & 1.43 & 0.05 & 29.33 \\
\hline Alternative & $2 \%$ & 0.008 & 0.00 & 0.18 \\
\hline Global power mix & $100 \%$ & 0.33 & 0.041 & 2.69 \\
\hline
\end{tabular}

hydropower and/or high water-related damage factors for power generation. In areas with high water scarcity, such as Egypt, water consumption contributes significantly to the environmental damage of all power producing technology groups (see ESM, Table S2), with the exception of fossil thermal electricity generation.

In the global power mix, water consumption makes up between $0.3 \%$ (low estimate) and $5.4 \%$ (high estimate) of the total environmental damage, with an average contribution of $1.3 \%$ (see ESM, Table S3). The use of fossil fuels and the emission of respiratory inorganics are the impact categories adding most to the overall damage score of global electricity production. Building on the error propagation calculations for the global electricity mix (see Section 2.4.2), water consumption impacts have the highest dispersion factors $(k=8.05)$, followed by radioactive emissions $(k=3.56)$, carcinogenic pollutants $(k=3.30)$ and land use $(k=3.24$; see ESM, Table S3). The $k$ factor for the overall damage score, in contrast, amounts to only 1.39 , assuming no correlation among impact categories.
3.3 Contrasting production mixes with market mixes

\subsubsection{North American electricity market}

The differences in water consumption and associated environmental damage between the production and market mixes of Mexico, Canada, and the USA are very low (Table 6), which correlates with the relatively low electricity trade. For all countries investigated, the water-consumption-related damage is low compared to other impact categories (see ESM, Fig. S1).

\subsubsection{Detailed analysis for the European electricity market}

Similar to the North American electricity market, countryspecific production and market mixes in general do not differ considerably in respect to water-consumption-related environmental damages (Fig. 3). In comparison to the production mixes, a relatively high increase in the water-consumption-related damages can only be observed for the Portuguese market mix
Fig. 2 Environmental damage of global average power production, quantified in EI99+ points (including water consumption). The global mix and individual power production technologies are assessed based on national electricity generation and related damage factors
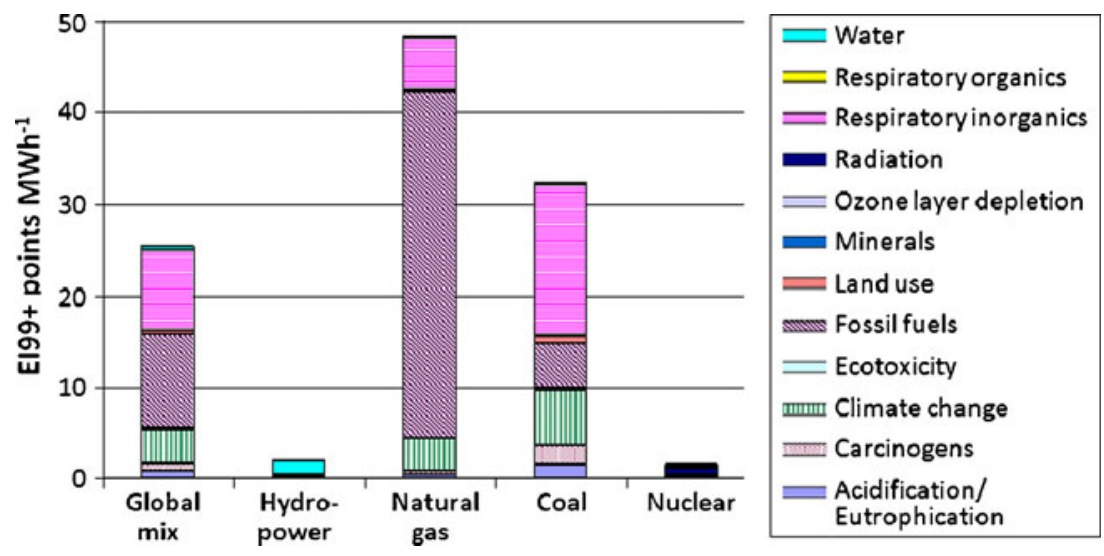
Table 5 Water consumption, the associated environmental damage and the total damage of national power production mixes

\begin{tabular}{|c|c|c|c|c|c|}
\hline \multirow[t]{2}{*}{ Country } & \multicolumn{2}{|c|}{ Water consumption } & \multirow{2}{*}{$\begin{array}{l}\text { Other categories } \\
\text { Damage } \\
\text { [EI99-pts/MWh] }\end{array}$} & \multirow{2}{*}{$\begin{array}{l}\text { Total damage } \\
\text { (EI99+) } \\
\text { [EI99-pts/MWh] }\end{array}$} & \multirow{2}{*}{$\begin{array}{l}\text { Water consumption } \\
\text { damage share } \\
{[\%]}\end{array}$} \\
\hline & $\begin{array}{l}\text { Inventory } \\
{\left[\mathrm{m}^{3} / \mathrm{MWh}\right]}\end{array}$ & $\begin{array}{l}\text { Damage } \\
\text { [EI99-pts/MWh] }\end{array}$ & & & \\
\hline Chile & 16.64 & 8.44 & 19.29 & 27.73 & 30 \\
\hline Afghanistan & 31.41 & 7.31 & 10.77 & 18.08 & 40 \\
\hline Namibia & 40.31 & 6.77 & 1.59 & 8.36 & 81 \\
\hline Kyrgyzstan & 26.87 & 5.79 & 5.58 & 11.36 & 51 \\
\hline Tajikistan & 32.32 & 5.36 & 1.19 & 6.54 & 82 \\
\hline Ethiopia & 34.12 & 4.19 & 0.79 & 4.98 & 84 \\
\hline Lesotho & 29.12 & 4.18 & 0.39 & 4.57 & 92 \\
\hline Egypt & 8.04 & 3.52 & 35.19 & 38.71 & 9 \\
\hline Pakistan & 15.75 & 3.50 & 25.97 & 29.47 & 12 \\
\hline Sudan & 15.68 & 2.57 & 27.94 & 30.51 & 8 \\
\hline Nepal & 20.30 & 2.28 & 0.39 & 2.67 & 85 \\
\hline Mozambique & 32.23 & 1.68 & 0.39 & 2.06 & 81 \\
\hline Peru & 23.43 & 1.65 & 9.24 & 10.89 & 15 \\
\hline Mali & 28.44 & 1.51 & 18.75 & 20.26 & 7 \\
\hline Iran & 5.41 & 1.46 & 36.72 & 38.18 & 4 \\
\hline Kenya & 22.64 & 1.42 & 13.33 & 14.76 & 10 \\
\hline Zimbabwe & 21.77 & 1.41 & 17.16 & 18.57 & 8 \\
\hline Malawi & 30.98 & 1.22 & 1.19 & 2.41 & 51 \\
\hline Syria & 6.01 & 1.13 & 36.32 & 37.45 & 3 \\
\hline Uzbekistan & 6.97 & 1.12 & 35.12 & 36.24 & 3 \\
\hline Zambia & 30.74 & 1.07 & 0.79 & 1.86 & 58 \\
\hline Morocco & 4.31 & 1.04 & 37.19 & 38.22 & 3 \\
\hline
\end{tabular}

Selection of countries sorted by the specific damage from water consumption

(48\%), while for Croatia and Austria the attributed water consumption impacts are lowered by roughly $20 \%$ through electricity trade. Considering the overall damage in EI99+ scores, the differences become more pronounced for some countries which are characterized by major international trade of electricity, such as an increase for Switzerland and Slovakia and a decrease for Luxembourg and Moldova (see ESM, Fig. S2).

\section{Discussion}

\subsection{Modeling approach and application}

The water consumption data applied in this study features high uncertainty as it is based mainly on estimates derived from various literature datasets. Although we found a good match among different sources, variability is relatively high within different technologies, especially for hydropower and alternative power production. For an adequate assessment of alternative power production options, more information on the specific technologies and their actual shares in the production mix would be required. Yet, alternative generation technologies generally play only a minor role in the national and global production mixes, when contrasted to hydropower. For hydropower, the different types of dams in operation cause significant variation in water consumption. These fluctuations very much depend on the hydraulic head of the power station and the relation between the water flow and the surface area of the pond or reservoir. In general, hydropower installa-
Table 6 Water consumption and related damage of electricity production and market mixes for Mexico, Canada, and the USA

\begin{tabular}{lccccc}
\hline Country & \multicolumn{2}{l}{ Water consumption $\left(\mathrm{m}^{3} / \mathrm{MWh}\right)$} & & \multicolumn{2}{l}{ Water-consumption-related damage (EI99+/MWh) } \\
\cline { 2 - 3 } \cline { 5 - 6 } & Production mix & Market mix & & Production mix & Market mix \\
\hline Canada & 15.52 & 15.20 & & 0.344 & 0.353 \\
Mexico & 4.28 & 4.29 & & 0.406 & 0.406 \\
United States & 6.19 & 6.29 & & 0.598 & 0.595 \\
\hline
\end{tabular}


Fig. 3 Environmental damages caused by water consumption in the electricity production and market mixes for different European countries, measured in EI99+ scores

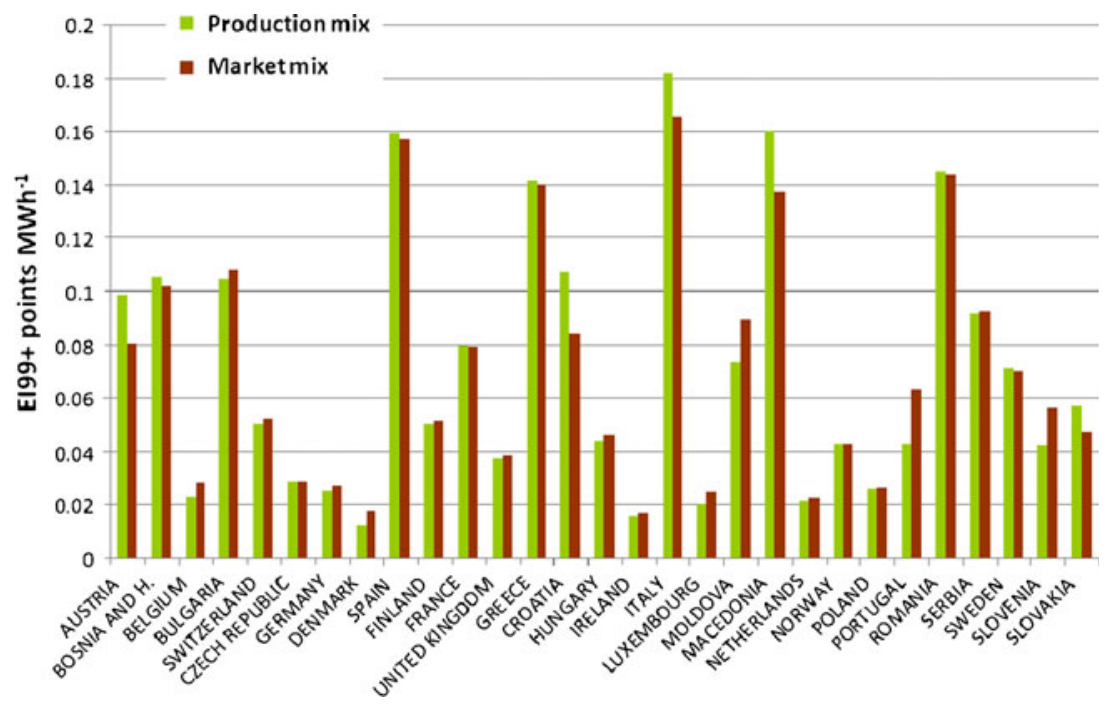

tions are differentiated in run-of-the-river plants with minimal storage, and reservoirs with large storage volumes. Operational and infrastructure details are, however, unique to each particular plant and hence are difficult to evaluate on a global scale. By implementing a climate-dependent modeling procedure for water consumption in hydropower production, we capture crucial parameters for evaporative losses and thus express part of the uncertainty as climatic variations within countries. For detailed analyses, assessment of individual hydropower plants including actual electricity amount generated, storage features, specific climatic conditions as well as allocation of the evaporative losses to electricity generation and other purposes (e.g., irrigation or flood control) is required. As our results allocate all water consumption of dams to power production, we overestimate the impact of hydropower production. For 2005, we calculated global water consumption by hydropower to amount to $65 \mathrm{~km}^{3} /$ year, which is $29 \%$ of estimated total consumptive water use from all reservoirs including those for irrigation and water resources management (222 $\mathrm{km}^{3} /$ year; Shiklomanov 2000). This share seems reasonable because irrigation, by far the most important water consumer, often directly uses runoff water or groundwater. Water consumption for infrastructure, as compared to the operation phase, seems only relevant for alternative power production technologies with low overall water consumption, such as photovoltaic, wind and small-scale hydropower plants. Such figures could be included in more detailed analyses of alternative power generation.

Despite these limitations, the global average estimates for water consumption values and EI99+ damage scores for specific generation technologies (see Table 2, Fig. 2 and ESM, Table S3) can serve as generic estimates, for instance, for simplified screening assessments and supply chain analyses. If electricity use proves to be crucial in a screening analysis, then the detailed LCA study should apply country-specific damage factors (as provided in the XLS file of the ESM) or perform a detailed analysis of individual power plants. The contribution to variance of power generation in the overall LCA damage score should then be considered in comparison to the uncertainty introduced by other interventions. However, for a proper analysis, all impact assessment factors would need uncertainty information to be coupled with the uncertainties of inventory flows.

\subsection{Regional and temporal aspects}

The regionally changing environmental performance of power generation is mainly driven by the respective national power production mixes and the related damage factors for water consumption. Adjusting the inventory and damage factors to a geographically explicit resolution finer than the country level, as presented in this work for thermal power production (see Section 2.6), would further improve the quality and representativeness of hydropower water consumption estimates and allow for enhanced accuracy of the impact assessment. The generation of such data is subject to further research. Since variability in national power production mixes was demonstrated to be significant in terms of water consumption and environmental damage, the global average estimates should therefore only be applied if no reliable information is at hand. Also, analysis of the supply chain processes such as water consumption of natural gas extraction should be further investigated including the related impacts: such water consumption impacts may become relevant where supply chains in water-stressed areas are involved in power production in water-abundant areas. 
Apart from the geographical dimension in power modeling, temporal aspects become important, as different market mixes could be chosen for an analysis depending on the season of the year or the time of day during which electricity is used. Such a temporal differentiation could reflect certain power generation practices, for instance storing water in pumped-storage hydropower plants (e.g., as practiced in Switzerland to buffer peak demands in Western Europe).

4.3 Relevance of water consumption in the overall life cycle assessment

Power production has been shown to be responsible for $40 \%$ of anthropogenic and $24 \%$ of total greenhouse gas (GHG) emissions (Stern 2007). Our study indicates that power-related water consumption only contributes $4 \%$ to the total global water consumption $\left(90 \mathrm{~km}^{3} /\right.$ year compared to $2291 \mathrm{~km}^{3} /$ year, status: 2005 Shiklomanov 2000). In this context, the trade-off between the water footprint and the carbon footprint of hydropower and fossil thermal electricity production becomes relevant: hydropower plants generally feature low GHG emissions, but consume substantially more water than thermal generation systems. Viable solutions to mitigate both, water stress and climate change, are alternative energy technologies such as photovoltaic and wind power together with nuclear power. However, the environmental performance of nuclear power is highly debatable as conventional LCA does not cover all relevant environmental damages (e.g., long-term effects of radioactive wastes). Biomass-based electricity production might be favorable in some cases, but due to the impacts related to the agricultural production of the biomass this electricity type needs to be carefully evaluated. Thermal power production using irrigated energy crops might even result in severe impacts from water consumption.

Comprehensive LCA studies which outline the unaggregated results for individual impact categories as required by the ISO standard on LCA (ISO 2006) are therefore important. Including water consumption impacts into the assessment of power production also questions the finding that "fossil energy use is identified by all methodologies as the most important driver of environmental burden of the majority of the commodities included, with the main exception of agricultural products" (Huijbregts et al. 2010) - if we consider electricity as a commodity. Similarly, a pure focus on the water footprint (Chapagain and Hoekstra 2004; Pfister and Hellweg 2009; Ridoutt and Pfister 2010) neglects significant environmental damages and related trade-offs, which should always be investigated from a comprehensive environmental perspective. Further relevant topics in power production are cooling water releases (thermal pollution) and in-stream water use for hydropower. For both interventions, framework methodologies have been developed (Verones et al. 2010; Humbert and Maendly 2009) but need additional refinement to be broadly applicable and to supply geographically resolved characterization factors. Previous results show that fossil thermal and nuclear power production is significantly affected by cooling water releases (Verones et al. 2010). This is especially relevant for the case of nuclear power which scores very low in current LCA studies. Impacts of dams on the ecosystems of downstream and upstream river sections seem to be also relevant for hydropower production (Humbert and Maendly 2009). Furthermore, the change in nutrient contents, sediment deposition, and GHG emissions of dams are so far widely neglected. In addition to such shortcomings, regionalized characterization factors for impact categories other than water consumption, such as eutrophication, acidification and land use, are needed to facilitate a more representative assessment of power generation.

The results of this study are based on the EI99 method and the water impact assessment method developed by Pfister et al. (2009a), which represents the current state of the art. Other methods may produce different results concerning the relevance of water consumption. A crosscomparison of the EI99+ results presented above with new results calculated with the ReCiPe method (Goedkoop et al. 2009; for implementation of the water consumption assessment into the ReCiPe method and the new impact scores computed see ESM) shows rather insignificant changes. However, the ReCiPe-aggregated damage assessment resulted generally in a higher relative weight of water consumption.

\subsection{Appropriate power mix}

Depending on the location of power use, different generation technologies are involved. We analyzed power production mixes on the global and national level to indicate the transfer of production-caused environmental damages to consumers in different countries. For Europe and North America, market mixes were calculated to better determine the involved power generation technologies in the electricity provision, including trade patterns. In contrast to our study, the electricity market mixes reported in the ecoinvent database (v2.1) do not account for reexports of imported electricity. This shortcoming has been shown here to have relatively low relevance on a country level for both water-related impacts as well as overall environmental performance, except for some nations with high trade shares such as Switzerland or Austria. Differences in total environmental damages (EI99+ scores) between the calculated market mixes and production mixes are more significant. For larger countries such as the USA, sub-national market mixes should be derived to achieve 
more precise estimates for the environmental footprint of power generation. If the focus changes from attributional to consequential LCA, the marginal technology needs to be defined for each electricity market using economic analysis. In addition to the technology type, the location of the marginal technology should be specified to appropriately assess the site-dependent impacts of water consumption. This information adds another dimension to the consequential approach providing a basis for optimizing power transmission and production prices. With the current data availability, however, consequential analyses have to be performed on a case by case basis. For an accurate analysis of power production, especially in a national or regional context, the trade with renewable energy certificates should be taken into account as the consumer can chose the power technology independent of the market mix. Such certificates can be included in the inventory while impacts of changed transmission patterns should be considered in future research.

\section{Conclusions}

Due to the enormous and still rising electricity use, water consumption in power production is relevant on a global scale. While agriculture is by far the most important water consumer, electricity use with its inherent water consumption impacts should be considered when assessing water consumption related environmental impacts of industrial processes. As such, the results of this study facilitate the inclusion of a considerable part of background water consumption and associated environmental damages of the majority of industrial processes. However, if biomass-based electricity generation is involved, a more comprehensive analysis of water consumption in the agricultural value chain is required. By providing regionalized damage values for water consumption and other environmental impacts in the electricity production of 208 countries, this work enables an enhanced assessment of electricity on a country level with a global coverage. The international trade of electricity is generally less important than differences in national production mixes, although in Europe electricity trade has some environmental relevance. Future studies should focus on improved modeling of hydropower water consumption, improved estimates of uncertainties, regionalized assessments of emissions, and consequential aspects, including trade of electricity, electricity certificates, and plant-specific buys.

Acknowledgments We thank Ben Dziegielewski for sharing background data, Michael Boesch for advising on power plants and Chris Mutel for suggestions regarding input-output modeling and English proofreading. This work was supported by the Seventh Framework Programme of the European Commission.

\section{References}

Bayart JB, Bulle C, Deschênes L, Margni M, Pfister S, Vince F, Koehler A (2010) A framework for assessing off-stream freshwater use in LCA. Int J Life Cycle Assess 15(5):439-453

Bosch ME, Hellweg S, Huijbregts MAJ, Frischknecht R (2007) Applying cumulative exergy demand (CEXD) indicators to the ecoinvent database. Int J Life Cycle Assess 12(3):181-190

Chapagain AK, Hoekstra AY (2004) Water footprints of nations: Volume 1: Main report. Research report series no. 16. UNESCOIHE, Delft, The Netherlands

Dziegielewski B, Bik T (2006) Water use benchmarks for thermoelectric power generation. Department of Geography and Environmental Resources. Southern Illinois University Carbondale

Energy Information Administration (2009) The international energy annual (IEA). http://www.eia.doe.gov/emeu/iea/contents.html. Accessed December 112009

ENTSO-E (2010) ENTSO-E Statistical database. https://www.entsoe. eu/index.php?id=67. Accessed:5 May 2010

EPRI (2002) U.S. Water consumption for power production - the next half century, technical report. Water \& Sustainability (Volume 3). Electric Power Research Institute (EPRI)

EPRI, U.S. Department of Energy (1997) Renewable energy technology characterizations. Washington, D.C, United States

FAO (2004) Global map of monthly reference evapotranspiration-10 arc minutes. FAO Geonetwork. http://www.fao.org/geonetwork/ srv/en/metadata.show

Feeley TJ, Pletcher S, Carney B, McNemar AT (2006) Department of energy/national energy technology laboratory's power plantwater R\&D program. Department of Energy/National Energy Technology Laboratory (DOE/NETL), avilable at: http://www. netl.doe.gov/technologies/coalpower/ewr/pubs/Power\%20Gen\% 202006_Water\%20R\&D.pdf

Frischknecht R et al (2007) Electricity mix and electricity grid (German: Strommix und stromnetz). Sachbilanzen von Energiesystemen: Grundlagen für den ökologischen Vergleich von Energiesystemen und den Einbezug von Energiesystemen in Ökobilanzen für die Schweiz. Paul Scherrer Institut Villigen, Swiss Centre for Life Cycle Inventories, Dübendorf, Switzerland

Frischknecht R, Steiner R, Jungbluth N (2008) Ökobilanzen: Methode der ökologischen knappheit-ökofaktoren 2006. Sr 28/2008. Öbu-Netzwerk für nachhaltiges Wirtschaften, Zurich, Switzerland

Fthenakis V, Kim HC (2010) Life cycle uses of water in U.S. electricity generation. Renew Sustain Energy Rev 14(7):20392048

Gleick PH (1994) Water and energy. Ann Rev Energ Env 19(1):267299

Goedkoop M, Spriensma R (2001) The eco-indicator 99: A damage oriented method for life cycle impact assessment: Methodology report. Publikatiereeks produktenbeleid; nr. 36a, 3rd edn. Ministerie van Volkshiusvesting, Ruimtelijke Ordening en Milieubeheer, Den Haag, The Netherlands

Goedkoop M, Heijungs R, Huijbregts M, De Schryver A, Struijs J, van Zelm R (2009) Recipe 2008 - a life cycle impact assessment method which comprises harmonised category indicators at the midpoint and the endpoint level. Available at http://lcia.wik.is

GWSP Digital Water Atlas (2008) Map 1: Water consumption of power plants (v1.0). Available online at http://atlas.Gwsp.Org

Huijbregts MAJ, Hellweg S, Frischknecht R, Hendriks HWM, Hungerbühler K, Hendriks AJ (2010) Cumulative energy demand as predictor for the environmental burden of commodity production. Environ Sci Technol 44(6):2189-2196 
Humbert S, Maendly R (2009) Characterization factors for damage to aquatic biodiversity caused by water use especially from dams used for hydropower. Paper presented at the LCA IX, Boston, 1 October 2009

IPCC (2007) In: Solomon SD, Qin M, Manning Z, Chen M, Marquis KB, Averyt M, Tignor, Miller HL (eds) Climate change 2007: The physical science basis. Cambridge University Press, Cambridge, United Kingdom and New York, United States

ISO (2006) ISO 14044: Environmental management-life cycle assessment-requirements and guidelines. International Organization for Standardization, Geneva, Switzerland

Kadigi RMJ, Mdoe NSY, Ashimogo GC, Morardet S (2008) Water for irrigation or hydropower generation? Complex questions regarding water allocation in Tanzania. Agr Water Manage 95(8):984-992

Leontief W (1970) Environmental repercussions and the economic structure: an input-output approach. Rev Econ Stat 52(3):262-271

Melillo JM, Reilly JM, Kicklighter DW, Gurgel AC, Cronin TW, Paltsev S, Felzer BS, Wang X, Sokolov AP, Schlosser CA (2009) Indirect emissions from biofuels: how important? Science 326 (5958):1397-1399

Mila i Canals L, Chenoweth J, Chapagain A, Orr S, Anton A, Clift R (2009) Assessing freshwater use impacts in LCA: part Iinventory modelling and characterisation factors for the main impact pathways. Int J Life Cycle Assess 14(1):28-42

National Atlas (2009) Major dams of the United States. http://www. nationalatlas.gov/mld/dams00x.html

New M, Lister D, Hulme M, Makin I (2002) A high-resolution data set of surface climate over global land areas. Clim Res 21(1):1-25

Peiu N (2007) Life cycle inventory study of the electrical energy production in Romania. Int J Life Cycle Assess 12(4):225-229

Pfister S, Hellweg S (2009) The water "Shoesize" Vs. Footprint of bioenergy. Proceedings of the National Academy of Sciences 106 (35):E93-E94

Pfister S, Koehler A, Hellweg S (2009a) Assessing the environmental impacts of freshwater consumption in LCA. Environ Sci Technol 43(11):4098-4104

Pfister S, Stoessel F, Juraske R, Koehler A, Hellweg S (2009b) Regionalized LCIA of vegetable and fruit production: Quantifying the environmental impacts of freshwater use. In: Nemecek T, Gaillard G (eds) 6th International Conference on LCA in the Agri-Food Sector-towards a sustainable management of the Food chain, Zurich, June (2009b). Agroscope ReckenholzTänikon Research Station ART, Switzerland, pp 16-22

Ribeiro FD, da Silva GA (2010) Life-cycle inventory for hydroelectric generation: a Brazilian case study. J Clean Prod 18(1):44-54
Ridoutt BG, Pfister S (2010) A revised approach to water footprinting to make transparent the impacts of consumption and production on global freshwater scarcity. Glob Environ Change 20(1):113120

Rockstrom J, Steffen W, Noone K, Persson A, Chapin FS, Lambin E, Lenton TM, Scheffer M, Folke C, Schellnhuber HJ, Nykvist B, de Wit CA, Hughes $\mathrm{T}$, van der Leeuw S, Rodhe H, Sorlin S, Snyder PK, Costanza R, Svedin U, Falkenmark M, Karlberg L, Corell RW, Fabry VJ, Hansen J, Walker B, Liverman D, Richardson K, Crutzen P, Foley J (2009) Planetary boundaries: exploring the safe operating space for humanity. Ecol Soc 14 (2):32

Shiklomanov IA (2000) Appraisal and assessment of world water resources. Water Int 25(1):11-32

Shiklomanov IA (2003) World water resources at the beginning of the 21 st century. International hydrology series. Cambridge University Press, Cambridge, United Kingdom

Slob W (1994) Uncertainty analysis in multiplicative models. Risk Anal 14(4):571-576

SN Energie Gruppe (2008) Aquapower switzerland, news 2_2008. http:// www.aquapower.ch/uploads/media/aquapower-news_2_2008.pdf. Accessed: June 2010

Solley WB, Pierce RR, Perlman HA (1998) Estimated use of water in the united states in 1995. U.S. GEOLOGICAL SURVEY CIRCULAR 1200. USGS, Denver, United States

Stern N (2007) Stern review: the economics of climate change. Cambridge University Press, Cambridge, United Kingdom

Stillwell AS, King CW, Webber ME, Duncan IJ, Hardberger A (2009) Energy-water nexus in Texas. The university of Texas at Austin, Austin, United States

Torcellini P, Long N, Judkoff R (2003) Consumptive water use for U. S. power production. National Renewable Energy Laboratory (NREL), Colorado, United States

United States Ecoinvent Centre (2008) Ecoinvent data v2.01. http:// www.ecoinvent.org

Verones F, Hanafiah M, Pfister S, Huijbregts MAJP, Gregory J, Koehler A (2010) Characterisation factors for thermal pollution in freshwater aquatic environments. Environ Sci Technol 44 (24):9364-9369

Weber CL, Jaramillo P, Marriott J, Samaras C (2010) Life cycle assessment and grid electricity: what do we know and what can we know? Environ Sci Technol 44(6):1895-1901

Zektser IS, Everett LG (2007) Groundwater resources of the world and their use. UNESCO Series on Groundwater BGR Hannover, Germany 